\title{
Stimulation of rat Sertoli cell secretory activity in vitro by germ cells and residual bodies
}

\author{
B. Le Magueresse, F. Le Gac*, M. Loir* and B. Jégou \\ Laboratoire de Biologie de la Reproduction, UA C.N.R.S. 256, and ${ }^{*}$ Laboratoire de Physiologie des \\ Poissons I.N.R.A., Campus Universitaire de Beaulieu, 35042 Rennes Cédex, France
}

\begin{abstract}
Summary. The direct influence of germ cells and residual bodies on Sertoli cell basal and FSH-stimulated secretion of androgen-binding protein (ABP) was studied using Sertoli cells, recovered from 20 -day-old rats, cultured alone or cocultured with a crude germ cell preparation from adult rats or with pachytene spermatocytes, round spermatids or populations of residual bodies enriched by centrifugal elutriation. The effect of a rat liver epithelial cell line (LEC) on Sertoli cell function was also tested. Addition of a crude germ cell preparation increased basal and FSH-stimulated ABP secretion. Pachytene spermatocytes and residual bodies adhered to the Sertoli cell monolayer to a much greater extent than did round spermatids. Addition of pachytene spermatocytes markedly enhanced basal and FSH-stimulated ABP secretion over 12 days of culture. Round spermatids and residual bodies stimulated ABP secretion although to a lesser extent than did spermatocytes. Furthermore, the increase of FSH-stimulated ABP levels was not maintained after 4 or 8 days of culture. LEC also enhanced basal and FSH-induced ABP levels but the increase of FSH-induced ABP production was only observed until Day 8 of culture. The influence of LEC on Sertoli cell secretion could be mediated through the production of an extracellular matrix. It is concluded that germ cells, particularly pachytene spermatocytes, can directly stimulate Sertoli cell secretory activity in vitro.
\end{abstract}

\section{Introduction}

Sertoli cells are thought to exert a major influence on germ cell differentiation, development and metabolism. In fact, they constitute the structural framework of the seminiferous tubule, they form the blood-testis barrier that isolates in a specific microenvironment the part of the seminiferous epithelium where meiosis occurs and they are targets for FSH and testosterone which are responsible for the initiation and maintenance of spermatogenesis (for review, see Ritzén, Hansson \& French, 1981). Furthermore, previous work suggests that Sertoli cells could exert an influence on germ cell development through secretion of different factors such as plasminogen activator (Lacroix, Smith \& Fritz, 1977), transferrin (Skinner \& Griswold, 1980), Sertoli cell growth factor (SGF) (Feig, Bellvé, Erickson \& Klagsbrun, 1980), lactate and pyruvate (Jutte et al., 1982; Le Gac et al., 1983).

Recent studies have also indicated that several Sertoli cell functions are modulated according to the associated stages of spermatogenesis, suggesting that, in turn, germ cells could influence Sertoli cell activity (Parvinen, 1982). This hypothesis is reinforced by in-vivo and in-vitro studies showing that, when germ cells are destroyed by different treatments, a decrease of Sertoli cell functions is observed (in vivo: Rich \& de Kretser, 1979; Kerr, Rich \& de Kretser, 1979; Jégou, Laws \& de Kretser, 1983, 1984a; Jégou, Peake, Irby \& de Kretser, 1984b; in vitro: Galdieri, Ziparo, Palombi, Russo \& Stefanini, 1981).

These observations prompted us to investigate, in vitro, the possibility of a direct influence of germ cells on Sertoli cell metabolism. 


\section{Materials and Methods}

Sertoli cell culture procedures. Sertoli cells were enzymically isolated from testes of 20-day-old Sprague-Dawley rats according to a method previously described (Dorrington, Roller \& Fritz, 1975). They were then seeded in $35 \mathrm{~mm}$ Nunc Petri dishes at a density of about $1 \times 10^{6}$ cells $/$ dish. Cell viability, assessed by the erythrosine dye-exclusion test was more than $95 \%$. The medium used for culture was Basal Eagle's Medium containing $25 \mathrm{mM}-H$ epes (BME; Gibco Europe, Flobio, France) with the addition of glutamine ( $(0 \cdot 3 \mathrm{~g} /$ litre), non-essential amino acids $(1 \%)$ and antibioticsantimycotics $(1 \%)$. The cells were incubated at $32^{\circ} \mathrm{C}$ in an humidified atmosphere of $5 \% \mathrm{CO}_{2}$ and $95 \%$ air. BME enriched with $10 \%$ fetal calf serum (FCS) was used for the first $48 \mathrm{~h}$ of culture and omitted thereafter. Since in the following experiments Sertoli cells were difficult to count, particular care was taken to randomize the distribution of the cells in the culture dishes. This allows us to assume that the variation in ABP levels observed could not result from the small differences of Sertoli cell number.

Preparation of germ cell suspension and separation by centrifugal elutriation. Germ cell suspensions were prepared from adult Sprague-Dawley rat testes by trypsin digestion and then separated by centrifugal elutriation using the Beckman rotor JE-6, according to procedures described by Meistrich, Longtin, Brock, Grimes \& Myles (1981). Four enriched fractions were collected: pachytene spermatocytes, round spermatids (steps 1-11), late spermatids (steps 16-19) and residual bodies. After collection, germ cells and residual bodies were concentrated by centrifugation at $500 \mathrm{~g}$ for $10 \mathrm{~min}$, then resuspended at desired concentrations in BME containing $10 \%$ FCS. Cell viability was tested using erythrosine and was found to be at least $95 \%$. Cells and residual bodies were identified on air-dried smears stained with periodic acid-Schiff and haematoxylin, and the purity of the fractions was estimated. The pachytene fraction was enriched at $85 \%$ (major contamination by spermatogonia and round spermatids). The early spermatid (contamination by late spermatids and spermatocytes) and residual body fractions (contamination by spermatids) were enriched at nearly $80 \%$. The late spermatid fraction was only enriched at $50 \%$ (contamination by round spermatids and residual bodies).

Epithelial cell preparation. The rat liver epithelial cell line used for cocultures was obtained from the liver of normal 10-day-old Fisher rats (Morel-Chany, Guillouzo, Trincal \& Szajnert, 1978) and was kindly provided by Dr Guguen-Guillouzo (INSERM U49, Rennes, France). These cells were collected by trypsinization $\left(0.5 \%, 5 \mathrm{~min}, 37^{\circ} \mathrm{C}\right)$ and then suspended at desired concentrations in medium containing $10 \% \mathrm{FCS}$. Viability assessed by the erythrosine dye-exclusion test was found to be at least $95 \%$. These cells expressed no hepatic functions.

Cocultures of Sertoli cells with germ cells or liver epithelial cells. On Day 1 of Sertoli cell culture, known numbers of crude or enriched germ cell preparations or liver epithelial cells were added to the Sertoli cell monolayer in $1 \mathrm{ml} \mathrm{BME}$ containing $10 \%$ FCS. After $24 \mathrm{~h}$ media were removed, unattached cells were counted and their viability tested (higher than $90 \%$ ). Serum-free medium $(1 \mathrm{ml})$ was then added to the cocultures. Care was taken to remove any trace of FCS which would interfere with the ABP assay. When specified $1 \mu \mathrm{g}$ NIH-oFSH-S15 was added per dish. Medium from each well was collected every $48 \mathrm{~h}$ for the duration of culture and replaced with fresh medium with or without FSH. All experiments were performed at least three times.

Androgen-binding protein $(A B P)$ assays. After collection, culture media were centrifuged for 15 $\min$ at $15000 \mathrm{~g}$. Samples were then stored at $-20^{\circ} \mathrm{C}$, in the presence of $10 \%(\mathrm{v} / \mathrm{v})$ glycerol for a maximum of 2 weeks. ABP levels were measured by equilibrium dialysis against $1 \mathrm{nM}-\left[{ }^{3} \mathrm{H}\right] 5 \alpha-$ dihydrotestosterone (DHT) (sp. act. $54 \mathrm{Ci} / \mathrm{mmol}$; Amersham International plc, U.K.) (Fritz, Rommerts, Louis \& Dorrington, 1976). In several experiments, ABP was also measured by steadystate polyacrylamide-gel electrophoresis (Ritzén, French, Weddington, Nayfeh \& Hansson, 1974). ABP concentrations were calculated from the measured total and free steroid concentrations and 
the known $K_{\mathrm{d}}$ of ABP for $5 \alpha$-DHT $(0.84 \mathrm{nM})$. Unless stated otherwise, all results are expressed as pmol ABP produced per dish during $48 \mathrm{~h}$ and are the mean \pm s.e.m. of 3 dishes, each assayed in duplicate. The within-assay variation was $7 \%$ and the between-assay variation was always $<10 \%$. Isolated germ cell fractions and liver epithelial cells were also cultured alone and culture media were assayed for the presence of androgen-binding protein(s). No trace of androgen-binding protein(s) was detected by either method in media conditioned by germ cells or liver epithelial cells.

Microscopic studies. At the end of the cultures, some dishes were stained with May-GrünwaldGiemsa for light microscopic observation while others were fixed with glutaraldehyde $(2 \cdot 5 \%)$, post-fixed with osmium tetroxide $(1 \%)$, dehydrated in alcohol, dried by $\mathrm{CO}_{2}$ substitution and gold coated for scanning electron microscopy on a JSM-35-FCS-SEM microscope.

Statistical analyses. Statistical significance of the results was determined by use of Student's $t$ test.

\section{Results}

Coculture of Sertoli cells and crude germ cells

When cultured in BME alone, Sertoli cells secreted ABP into the medium whereas germ cells did not. Addition of a crude germ cell preparation to the Sertoli cell culture resulted in a highly significant increase of basal $(P<0.001)$ and FSH-stimulated $(P<0.01)$ ABP secretion (Fig. 1).

Adhesiveness of pachytene spermatocytes, early spermatids and residual bodies to Sertoli cells

Germ cells and residual bodies were first tested for their ability to adhere to the Sertoli cell

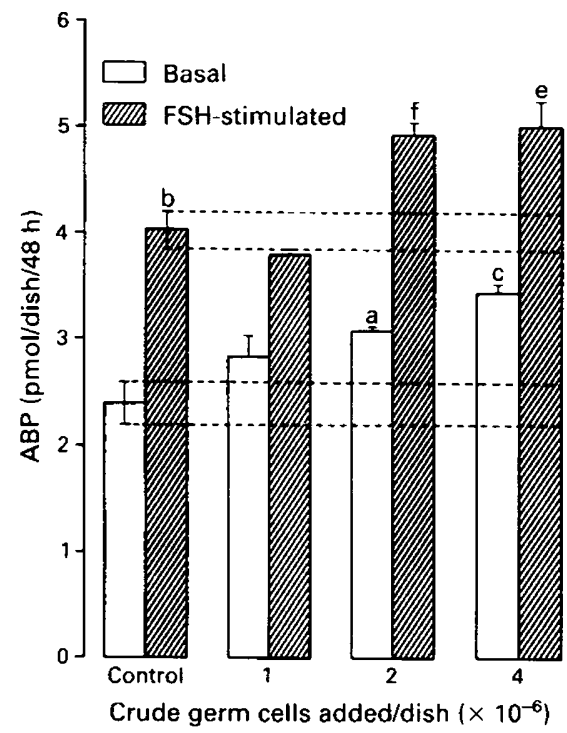

Fig. 1. Effects of increasing concentrations of crude germ cell preparation on basal and FSH-stimulated ( $1 \mu \mathrm{g} \mathrm{NIH-oFSH-S15}$ per dish) ABP secretion by rat Sertoli cells over a period of $48 \mathrm{~h}$ (Days $2-4$ of culture). Values are mean \pm s.e.m. for 3 dishes each assayed in duplicate. ${ }^{\mathrm{a}} P<0.05 ;{ }^{\mathrm{b}} P<0.01 ;{ }^{\mathrm{c}} P<0.001$ compared to basal control. ${ }^{\mathrm{e}} P<0.01 ;{ }^{\mathrm{f}} P<0.001$ compared to FSH-stimulated control. 

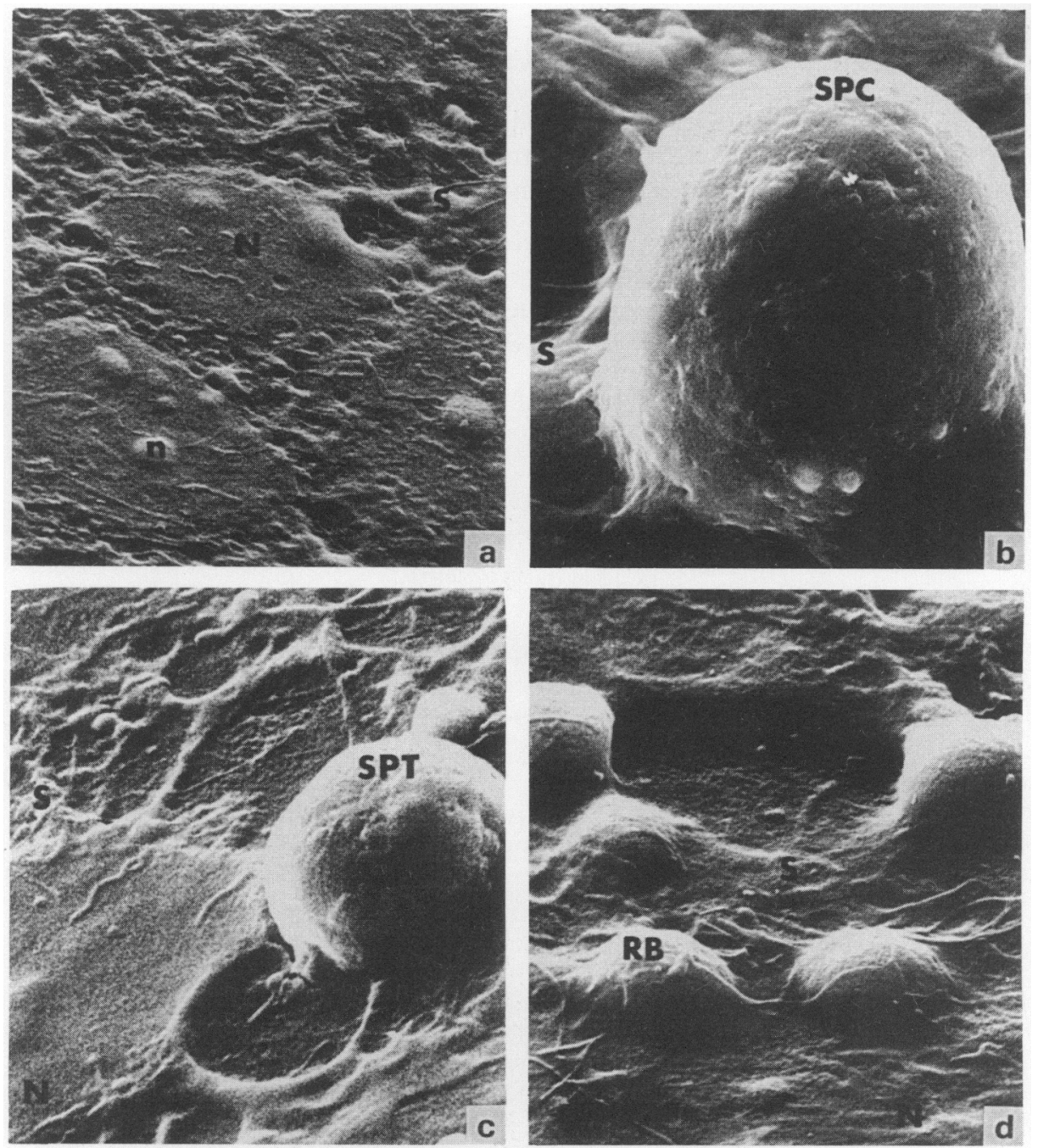

Fig. 2. Scanning electron micrographs of: (a) a primary culture of Sertoli cells (S) from a 20-day-old rat ( $\mathrm{N}=$ nucleus, $\mathrm{n}=$ nucleolus), $\times 2000$; and (b) a pachytene spermatocyte (SPC), $\times 3500$; (c) a round spermatid $(\mathrm{SPT}), \times 3500$; (d) residual bodies $(\mathrm{RB}, \times 3500$, adhering to the Sertoli cell monolayer.

monolayer. Figure 2 shows the appearance of Sertoli cells cultured alone, and in cocultures with pachytene spermatocytes, early spermatids or with residual bodies. All three classes of enriched preparations appeared to adhere to the Sertoli cells and some residual bodies seemed to have been phagocytosed. However, differences were seen in the proportion of cells adhering in each category (Fig. 3). For example when $4 \times 10^{6}$ cells were added, $90 \%$ of spermatocytes, $75 \%$ of residual bodies and only $50 \%$ of round spermatids were bound to the Sertoli cell monolayers. Furthermore, adhesiveness of spermatids and spermatocytes were both saturable whilst residual bodies continued to bind to the monolayers although to a lesser extent as numbers were increased.

\section{Effects of different concentrations of enriched germ cell preparations on ABP production}

The addition of the two classes of germ cells tested and of residual bodies to Sertoli cells resulted in an increase $(P<0.001)$ of basal and FSH-stimulated ABP secretion assayed on Day 4 of culture 
(Fig. 4). The most striking stimulations were obtained when spermatocytes were added. However, the relative response, i.e. Sertoli cells + germ cells + FSH versus Sertoli cells + germ cells, decreased when germ cell concentrations were augmented. This was not due to a decrease of FSHinduced ABP production but essentially to a proportionally greater stimulation of basal ABP production.

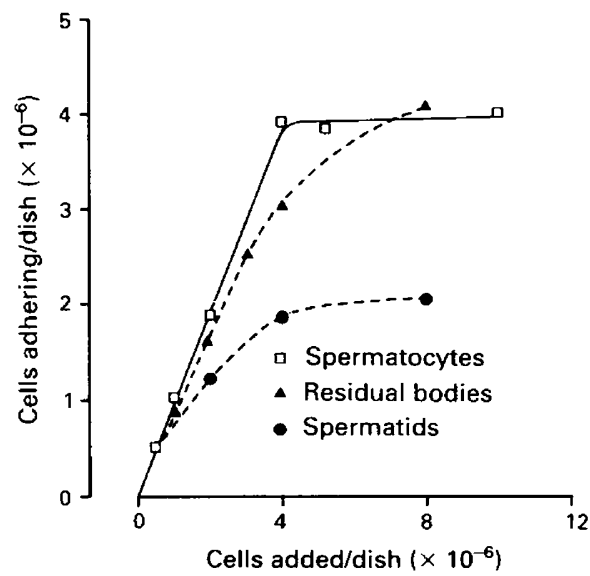

Fig. 3. In-vitro adhesion of pachytene spermatocytes, early spermatids and residual bodies to rat Sertoli cells. Known numbers of each enriched fraction were added to dishes $\left(10 \mathrm{~cm}^{2}\right)$ containing Sertoli cells, on Day 1 of culture. The media were collected $24 \mathrm{~h}$ later and the unattached cells were counted. Each point represents the difference between cells added and floating cells.

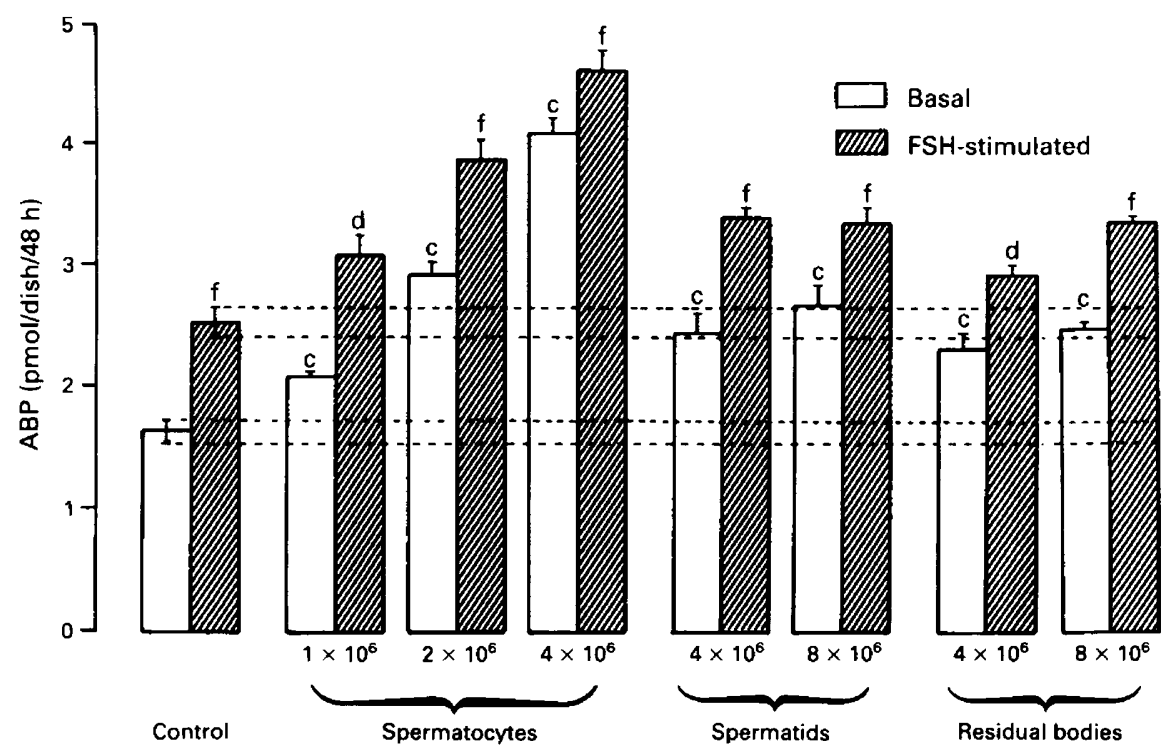

Fig. 4. Effects of enriched fractions containing pachytene spermatocytes, early spermatids and residual bodies on ABP secretion by rat Sertoli cells over a period of $48 \mathrm{~h}$ (Days 2-4 of culture). For spermatocytes, 90-100\% adherence for $1 \times 10^{6}, 2 \times 10^{6}$ and $4 \times 10^{6}$ cells added. For spermatids, $1.8 \times 10^{6}$ and $2 \times 10^{6}$ cells estimated attached for $4 \times 10^{6}$ and $8 \times 10^{6}$ cells added. For residual bodies, $3 \times 10^{6}$ and $4 \times 10^{6}$ cells attached for $4 \times 10^{6}$ and $8 \times 10^{6}$ added. Values are mean \pm s.e.m. for 3 dishes each assayed in duplicate. ${ }^{c} P<0.001$ when compared to basal control; ${ }^{\mathrm{d}} P<0.05$; $^{\mathrm{f}} P<0.001$ when compared to FSH-stimulated control. 


\section{Effects of the duration of culture and cocultures on Sertoli cell ABP secretion}

Basal ABP production by Sertoli cells alone decreased between Days 2-4 and 6-8 of culture $(P<0.001$; Fig. 5) and subsequently stabilized (Days $8-12)$ to levels corresponding to about $34 \%$ of the initial basal ABP secretion. When Sertoli cells were stimulated with FSH, ABP secretion increased on Days 4-6 $(P<0.001)$, then returned to initial values until Days 8-10 of culture before decreasing slightly $(P<0.001)$ on Days 10-12.

The addition of any concentration of spermatocytes resulted in a significant increase of basal and FSH-stimulated ABP production over the duration of the culture (Figs 5a, b). In such

(a) $+1 \times 10^{6}$ spermatocytes

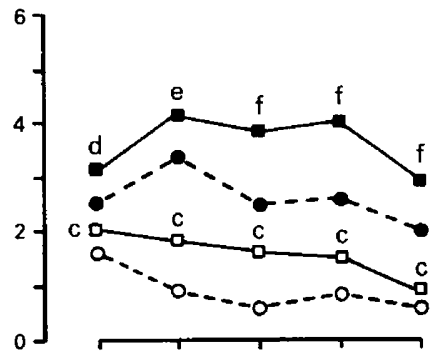

(c) $+4 \times 10^{6}$ round spermatids

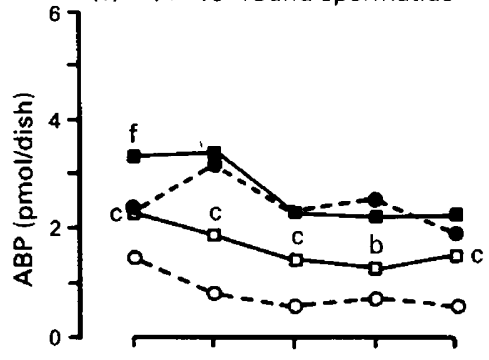

(e) $+4 \times 10^{6}$ residual bodies

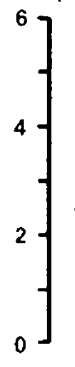

$$
c
$$

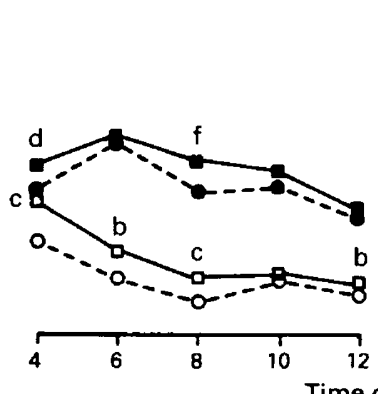

Time of culture (days)

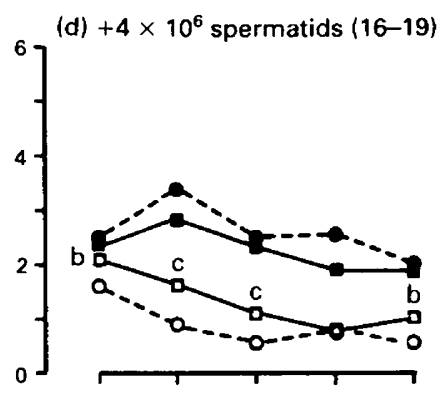

(f) $+1 \times 10^{6}$ LEC

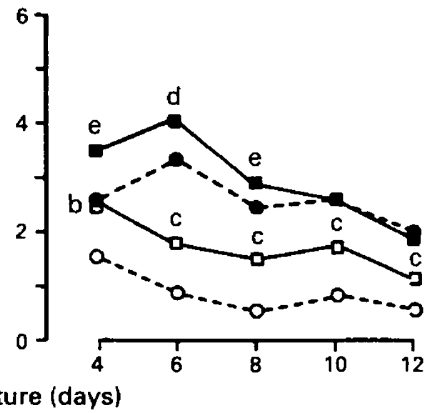

Fig. 5. Effects of enriched fractions containing pachytene spermatocytes $(a, b)$, round spermatids (c), elongated spermatids (d), residual bodies (e) and of a liver epithelial cell line (f) on ABP secretion by rat Sertoli cells over 12 days of culture. Values given are the means of 3 dishes, each assayed in duplicate. S.e.m., which never exceeded $12 \%$, are omitted for clarity. $O_{-}-O_{\text {, }}$ Basal ABP secretion by Sertoli cell-only culture; - - - 9 , FSH-stimulated ( $1 \mu \mathrm{g} \mathrm{NIH-oFSH}-$ S15 per dish) ABP secretion by Sertoli cell-only culture. These 2 curves are plotted on each graph to facilitate comparisons. $\square-\square$, Basal ABP secretion in coculture. $\square-\square$, FSHstimulated ABP secretion in coculture. ${ }^{\mathrm{a}} P<0.05 ;{ }^{\mathrm{b}} P<0.01 ;{ }^{\mathrm{c}} P<0.001$, when compared to basal ABP levels in Sertoli cell-only culture. ${ }^{\mathrm{d}} P<0.05$; $^{\mathrm{e}} P<0.01$; $^{\mathrm{f}} P<0.001$ when compared to FSH-stimulated ABP values in Sertoli cell-only culture. 


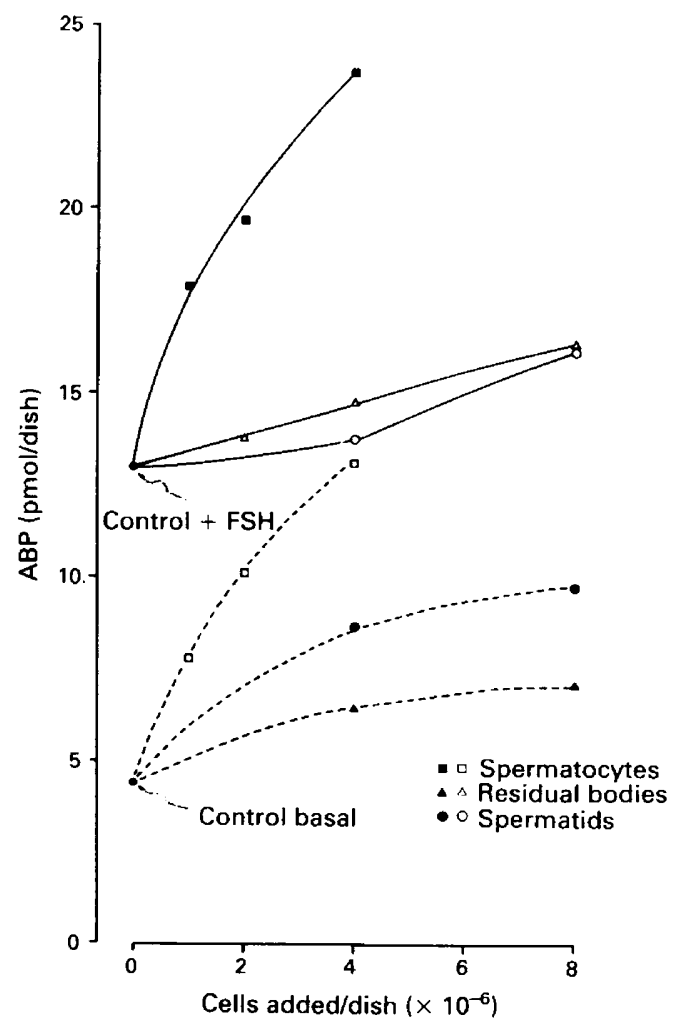

Fig. 6. Effects of increasing concentrations of pachytene spermatocytes, round spermatids and residual bodies on basal (broken lines) and FSH-stimulated ( $1 \mu \mathrm{g} \mathrm{NIH-oFSH-S15}$ per dish) (solid lines) cumulative ABP production. Culture media were collected for ABP assay and replaced every $48 \mathrm{~h}$. Each value represents the cumulative mean of triplicate dishes from the beginning of the culture (Day 2 of culture) to the end (Day 12).

cocultures basal secretion was maintained at the initial level until Day 6 and thereafter, although still significantly enhanced when compared to controls $(P<0.001)$, it gradually decreased. In the presence of $1 \times 10^{6}$ spermatocytes (Fig. 5a), FSH-stimulated ABP secretion increased on Day 6 of culture $(P<0.05)$ compared to Day 4 . This increase was maintained until Day 10 when it returned to the initial values. With $4 \times 10^{6}$ spermatocytes (Fig. 5b), FSH-stimulated ABP production was enhanced at Day 6 of culture but slowly decreased thereafter. However, FSH-stimulated ABP concentrations still represents $86 \%$ of initial values at the end of the coculture.

When $4 \times 10^{6}$ early spermatids were added to the Sertoli cell monolayer (Fig. 5c) basal ABP production was increased $(P<0.01)$ over the duration of the culture. However, early spermatids did not prevent the progressive decline of ABP production which occurred between Days 4 and 8 . At the end of the experiment basal ABP values corresponded to $60 \%$ of initial basal coculture values. Significant stimulation of FSH-stimulated ABP production was only seen at Day 4 of culture $(P<0.001)$.

Cocultures with late spermatids (steps 16-19) (Fig. 5d) resulted in a slight increase $(P<0.01)$ of basal ABP secretion on Days 2-4, 4-6, 6-8, and 10-12, whereas under these conditions FSHstimulated secretion was unchanged.

Residual bodies were also able to increase basal ABP secretion significantly (Fig. 5e). At the end of the coculture this secretion was reduced by more than half compared to the initial values. In the 
presence of residual bodies, FSH-stimulated production was significantly enhanced only on Days 2-4 and Days 6-8.

Epithelial cells used in this study enhanced both basal and FSH-stimulated ABP secretion. However, only basal ABP secretion was stimulated by the liver epithelial cells over the duration of the coculture. Stimulatory effects on FSH-induced ABP secretion disappeared after Day 8 of culture (Fig. 5f).

\section{Effects of long-term cocultures on cumulative ABP production}

When results were expressed as cumulative ABP production (Fig. 6), addition of spermatocytes markedly enhanced basal ABP secretion as well as FSH-stimulated production: $4 \times 10^{6}$ spermatocytes were able to stimulate basal ABP secretion to levels comparable to those observed when a high dose of FSH was added to Sertoli cells alone $(+189 \%)$. Since basal ABP levels increased to a proportionally greater extent than FSH-induced ABP levels (Fig. 4), the relative response decreased as spermatocyte numbers were augmented. The effect of residual bodies and round spermatids upon ABP production were proportionally greater basally than in the presence of FSH (Fig. 6).

\section{Discussion}

During the past few years it has been established that Sertoli cell function is modified by the influence of neighbouring germ cells. Indeed, several Sertoli cell characteristics vary in different stages of the seminiferous epithelium cycle (for review, see Parvinen, 1982). Furthermore, a close correlation has been shown between the state of spermatogenesis in different experimental situations and Sertoli cell function (Jégou et al., 1983, 1984a, b). The influence of germ cells upon Sertoli cell metabolism has also been studied by using cell culture systems. Using this approach, Ziparo, Geremia, Russo \& Stefanini (1980) have demonstrated that pachytene spermatocytes adhere much better to cultured Sertoli cells than do round spermatids; the mechanism involved in such surface recognition appeared to be specific and due to membrane glycoproteins (d'Agostino, Monaco, Stefanini \& Geremia, 1984). Galdieri, Monaco \& Stefanini (1984) have shown that pachytene spermatocytes but not early spermatids were able, in short-term cocultures $(40-70 \mathrm{~h})$, to stimulate FSH-induced ABP secretion.

The present study demonstrates that addition of a crude germ cell suspension to Sertoli cells in culture results in a highly significant increase of basal and FSH-stimulated ABP production. It reveals that pachytene spermatocytes are the main cells influencing ABP levels and that these cells possess the unique capacity to enhance FSH-stimulated ABP secretion over at least 12 days of culture. However, these cells are not able to prevent the progressive decrease of ABP secretion which occurs when Sertoli cell cultures are prolonged. Furthermore, our data show that round spermatids also enhance basal ABP production whereas the increase in FSH-stimulated production was not maintained beyond a few days of culture. The reason why this type of germ cell failed to stimulate FSH-induced ABP production in the experiments of Galdieri et al. (1984) may be due to differences in the experimental conditions. The present work confirms the better adhesiveness of spermatocytes than of round spermatids and clearly shows that the influence of the two classes of germ cells is proportional to their ability to adhere to the Sertoli cells.

Results of these in-vitro studies are in agreement with the in-vivo observations of Russell (1977) showing that desmosome-like sites are extensive and highly developed between Sertoli cells and pachytene spermatocytes whereas they are rarely observed between Sertoli cells and round spermatids. The increase in FSH-induced ABP secretion observed by Galdieri et al. (1984), when pachytene spermatocytes were added to Sertoli cell cultures was prevented by the presence of an 
agar layer stratified above the Sertoli cell monolayer. This indicates that membrane interactions may be necessary for the expression of the germ cell influence.

According to Russell (1980), "another unresolved problem relates to the mechanism by which the residual body is selectively retained within the seminiferous tubule". Our study reveals that residual bodies adhere very well to Sertoli cells in vitro and our microscopic observations suggest that they might be phagocytosed. Roosen-Runge (1952) and Lacy (1960) have speculated that the release of residual bodies by elongated spermatids and their ingestion by Sertoli cells might in some way trigger the development of early generations of germ cells. However, this hypothesis has not been substantiated experimentally. Our in-vitro results indicate that the influence of residual bodies on ABP secretion is much less important than that of pachytene spermatocytes and comparable to that of round spermatids. This does not necessarily mean that the influence of residual bodies on Sertoli cell metabolism is negligible since only the effect on ABP production was evaluated. The present demonstration of a Sertoli cell-residual body membrane recognition mechanism provides a useful in-vitro preparation to identify particular molecules that might mediate cell-cell adhesion and to study the fate and the role of residual bodies on Sertoli cell function and spermatogenesis.

Our study indicates that coculture of Sertoli cells with a liver epithelial cell type enhances ABP production. However, its influence on FSH-stimulated secretion is not maintained after several days of coculture. The structure of the coculture of Sertoli cells and germ cells is very different from that of Sertoli cells and liver epithelial cells. Whereas germ cells adhered to Sertoli cells but not to plastic dishes, liver epithelial cells only occupied the area of the culture dishes not covered by Sertoli cells. These liver epithelial cells have been selected for their ability, when cocultured with rat hepatocytes, to produce an extracellular matrix and to favour hepatocyte survival and activity (GuguenGuillouzo et al., 1983). It is therefore likely that their effects on Sertoli cell function differ from those of germ cells but are comparable to those induced by peritubular myoid cells or embryonic fibroblasts (Tung \& Fritz, 1980, 1984; Hutson \& Stocco, 1981).

In summary, this study demonstrates, by a direct approach, that pachytene spermatocytes, and to a much lesser extent round spermatids and residual bodies, may exert a stimulatory effect on Sertoli cell activity in vitro. The interaction between mature germ cells and immature Sertoli cells leads us to speculate that, in vivo, the increase in number of rat pachytene spermatocytes and other germ cells at about 20 days of age and older (De Jong \& Sharpe, 1977) could play a role in the onset and increase of ABP production (Tindall \& Means, 1976). This may similarly affect other changes which occur at the same time such as those of plasminogen activator (Lacroix et al., 1977). In conclusion, these results are consistent with the hypothesis of a local action of germ cells on Sertoli cells for the regulation of spermatogenesis.

We thank Dr J. E. Le Lannic for helpful advice on scanning microscope techniques; Dr C. Guguen-Guillouzo for the gift of the liver epithelial cells; Mr D. Blanchet and Mrs M. Mathelier for expert assistance in the preparation of the manuscript; Mrs J. Hall for help with the English; and the National Institutes of Health, Bethesda, U.S.A., for the ovine FSH preparation (NIH o FSH-S15).

This work was supported by a grant from INSERM (Institut National des Sciences et de la Recherche Médicale; NO. 844010).

\section{References}

d'Agostino, A., Monaco, L., Stefanini, M. \& Geremia, R. (1984) Study of the interaction between germ cells and Sertoli cells, in vitro. Expl Cell Res. 150, 430-435.

De Jong, F.H. \& Sharpe, R.M. (1977) The onset and establishment of spermatogenesis in rats in relation to gonadotrophin and testosterone levels. J. Endocr. 75, 197-207.
Dorrington, J.H., Roller, N.F. \& Fritz, I.B. (1975) Effects of follicle stimulating hormone on cultures of Sertoli cell preparations. Molec. cell. Endocr. 3, 57-70.

Feig, L.A., Bellvé, A.R., Erickson, N.H. \& Klagsbrun, M. (1980) Sertoli cells contain a mitogenic polypeptide. Proc. natn. Acad. Sci. U.S.A. 77, 47-74.

Fritz, I.B., Rommerts, F.F.G., Louis, B.G. \& Dorrington, 
J.H. (1976) Regulation by FSH and dibutyryl cyclic AMP of the formation of androgen-binding protein in Sertoli cell enriched cultures. J. Reprod. Fert. 46, 17-24.

Galdieri, M., Ziparo, E., Palombi, F., Russo, M.A. \& Stefanini, M. (1981) Pure Sertoli cell cultures: a new model for the study of somatic-germ cell interactions. J. Androl. 5, 249-259.

Galdieri, M., Monaco, L. \& Stefanini, M. (1984) Secretion of androgen binding protein by Sertoli cells is influenced by contact with germ cells. J. Androl. 5, 409-415.

Guguen-Guillouzo, C., Clement, B., Bafiet, G., Beaumont, G., Morel-Chany, E., Glaise, D. \& Guillouzo, A. (1983) Maintenance and reversibility of active albumin secretion by adult rat hepatocytes co-cultured with another liver epithelial cell type. Expl Cell Res. 143, 47-54.

Hutson, J.C. \& Stocco, D.M. (1981) Peritubular cell influence on the efficiency of androgen-binding protein secretion by Sertoli cells in culture. Endocrino$\log y$ 108, 1362-1368.

Jégou, B., Laws, A.O. \& de Kretser, D.M. (1983) The effect of cryptorchidism and subsequent orchidopexy on testicular function in adult rats. $J$. Reprod. Fert. $69,137-145$.

Jégou, B., Laws, A.O. \& de Kretser, D.M. (1984a) Changes in testicular function induced by short-term exposure of the rat testis to heat. Further evidence for interaction of germ cells, Sertoli cells and Leydig cells. Int. J. Androl. 7, 244-257.

Jégou, B., Peake, R.A., Irby, D.C. \& de Kretser, D.M. (1984b) Effects of the induction of experimental cryptorchidism and subsequent orchidopexy on testicular function in immature rats. Biol. Reprod. 30, 179-187.

Jutte, N.H.P.M., Jansen, R., Grootegoed, J.A., Rommerts, F.F.G., Clausen, O.P.F. \& Van Der Molen, H.J. (1982) Regulation of survival of rat pachytene spermatocytes by lactate supply from Sertoli cells. J. Reprod. Fert. 65, 431-438.

Kerr, J.B., Rich, K.A \& de Kretser, D.M. (1979) Effects of experimental cryptorchidism on the ultrastructure and function of the Sertoli cell and peritubular tissue of the rat testis. Biol. Reprod. 20, 409-422.

Lacroix, M., Smith, F.E. \& Fritz, I.B. (1977) Secretion of plasminogen activator by Sertoli cell enriched cultures. Molec. cell. Endocr. 9, 227-240.

Lacy, D. (1960) Light and electron microscopy, and its use in the study of factors influencing spermatogenesis in the rat. $J l R$. microsc. Soc. 79, 209-225.
Le Gac, F., Attramadal, M., Borrebaek, B., Horn, R., Froysa, A., Tvermyr, M. \& Hansson, V. (1983) Effects of FSH, isoproterenol and cyclic AMP on the production of lactate and pyruvate by cultured Sertoli cells. Archs Androl. 10, 149-154.

Meistrich, L.M., Longtin, J., Brock, W.A., Grimes, S.R. \& Myles, L.M. (1981) Purification of rat spermatogenic cells and preliminary biochemical analysis of these cells. Biol. Reprod. 25, 1065-1077.

Morel-Chany, E., Guillouzo, C., Trincal, G. \& Szajnert, M.F. (1978) 'Spontaneous' neoplastic transformation in vitro of epithelial cell strains of rat liver: cytology growth \& enzymatic activities. Eur. J. Cancer 14, 1341-1352.

Parvinen, M. (1982) Regulation of the seminiferous epithelium. Endocrine Reviews 3, 404-417.

Rich, K.A. \& de Kretser, D.M. (1979) Effect of fetal irradiation on testicular receptors and testosterone response to gonadotrophin stimulation in adult rats. Int. J. Androl. 2, 343-352.

Ritzén, E.M., French, F.S., Weddington, S.C., Nayfeh, S.N. \& Hansson, V. (1974) Steroid binding in polyacrylamide gels quantitation at steady-state conditions. J. biol. Chem. 249, 6597-6604.

Ritzén, E.M., Hansson, V. \& French, F.S. (1981) The Sertoli cell. In The Testis, vol. 8, pp. 171-194. Eds H. Burger \& D. M. de Kretser. Raven Press, New York.

Roosen-Runge, E.C. (1952) Kinetics of spermatogenesis in mammals. Ann. N.Y. Acad. Sci. 55, 574584.

Russell, L. (1977) Desmosome-like junctions between Sertoli cells and germ cells in the rat testis. Am.J. Anat. 148, 313-328.

Russell, L.D. (1980) Sertoli-germ cell interrelations: a review. Gamete Res. 3, 179-202.

Skinner, M.K. \& Griswold, M.D. (1980) Sertoli cells synthesize and secrete transferrin-like protein. J. biol. Chem. 225, 9923-9925.

Tindall, D.J. \& Means, A.R. (1976) Concerning the hormonal regulation of $\mathrm{ABP}$ in rat testis. Endocrinology 103, 589-594.

Tung, P.S. \& Fritz, I.B. (1980) Interactions of Sertoli cells with myoid cells in vitro. Biol. Reprod. 23, 207-217.

Tung, P.S. \& Fritz, I.B. (1984) Extracellular matrix promotes rat Sertoli cell histotypic expression in vitro. Biol. Reprod. 30, 213-229.

Ziparo, E., Geremia, R., Russo, M.A. \& Stefanini, M. (1980) Surface interactions in vitro between Sertoli cells and germ cells at different stages of spermatogenesis. Am. J. Anat. 159, $385-388$. 